\section{Long-term follow-up of Molteno drains used in the treatment of glaucoma presenting in childhood}

\begin{abstract}
Purpose and methods This study reviews the long-term follow-up (mean 11.2 years, range 9 months to 16 years 9 months) of Molteno drains used in the treatment of glaucoma presenting in childhood, in 34 eyes of 25 patients.

Results Intraocular pressure control was achieved in $85 \%$ of eyes, and vision (where measurable) was maintained in $57 \%$ of eyes. Seventy-one per cent of eyes required further surgical intervention. Thirty-two per cent of these cases were for drain-related problems, which may be avoidable with the use of current surgical techniques. The remaining interventions were for associated ocular defects, and for problems caused by multiple surgical procedures and periods of high intraocular pressure during early childhood. Conclusions Today the implants are used at an earlier stage in the disease process to try to obtain early and definitive IOP control and so help to optimise the long-term visual prognosis.
\end{abstract}

Key words Childhood glaucoma, Follow-up, Molteno drain

The use of Molteno drains in glaucoma presenting in childhood is usually reserved for eyes that have failed previous surgical procedures or are unlikely to respond to such procedures. In this study we have examined the long-term follow-up of a group of eyes that received Molteno drains for glaucoma presenting in childhood. The eyes in this series that were initially treated were complex cases that had often undergone multiple previous surgical procedures and the drains were inserted as a final attempt to control intraocular pressure (IOP). The initial drains were also performed as a two-stage procedure. As techniques developed with time, the drains were inserted as a one-stage procedure with the use of a Vicryl tie. Some of the eyes in this series formed the basis of a previous report. ${ }^{1}$
Primary congenital glaucoma is often managed surgically with either goniotomy or trabeculectomy and encouraging success rates (over 90\%) have been reported in selected cases with both these procedures, ${ }^{2-7}$ but more than one procedure may be required. Primary trabeculectomy for congenital glaucoma has been shown to have a good success rate ${ }^{8-10}$ and is considered the treatment of choice by some authors. ${ }^{11}$ The use of beta-irradiation ${ }^{12}$ with trabeculectomy or antimetabolites ${ }^{13,14}$ may improve the success rate of trabeculectomy even further; however, a note of caution has been raised with their use in juvenile patients. ${ }^{15}$ The combined procedure of trabeculotomy-trabeculectomy also has good reported success rates. ${ }^{9}$

Other studies have reported less successful outcomes with trabeculectomy performed in children and young people. ${ }^{16-20}$ Secondary glaucoma such as glaucoma associated with Sturge-Weber syndrome ${ }^{21}$ or aniridia ${ }^{22}$ or glaucoma secondary to surgery for congenital cataracts, and primary glaucoma in which initial goniotomy or trabeculotomy procedures have failed, may prove more difficult to treat. Where these initial procedures fail, further treatment options for control of glaucoma include cyclocryotherapy ${ }^{23-26}$ (which may be associated with significant complications) and the use of drainage implants such as the Molteno drain. ${ }^{1,28-37}$

\section{Subjects and methods}

Patients with glaucoma presenting in childhood before the age of 10 years who received a Molteno drain before the age of 30 years and who were operated on within this department, were identified from a data base of Molteno drains. A case note review of these eyes was then performed to establish their long-term follow-up, with particular reference to IOP control, visual acuity, and complications and further surgery. Where patients had left the area, their current ophthalmologist was contacted for follow-up. One eye was lost to

\author{
I.A. Cunliffe \\ A.C.B. Molteno \\ Department of \\ Ophthalmology \\ University of Otago Medical \\ School \\ Dunedin Hospital \\ Great King Street \\ Dunedin \\ New Zealand \\ Tel: 006434747970 \\ Fax: 006434747268 \\ I.A.C. is in receipt of an \\ Ethicon Travel Fellowship \\ from the Royal College of \\ Ophthalmologists and the \\ Royal College of Physicians \\ and Surgeons of Glasgow. \\ A.C.B.M. declares a \\ financial interest in \\ Molteno ${ }^{\circledR}$ implants
}




\begin{tabular}{|c|c|c|c|c|c|c|c|c|c|c|c|}
\hline \multirow[b]{2}{*}{ Eye } & \multirow[b]{2}{*}{ Diagnosis } & \multirow[b]{2}{*}{$\mathrm{R} / \mathrm{L}$} & \multirow[b]{2}{*}{ Age } & \multirow{2}{*}{$\begin{array}{l}\text { Previous } \\
\text { treatment }\end{array}$} & \multicolumn{2}{|c|}{$\mathrm{IOP}(\mathrm{mmHg})$} & \multirow[b]{2}{*}{ Treatment } & \multirow{2}{*}{$\begin{array}{l}\text { Visual } \\
\text { acuity }\end{array}$} & \multicolumn{3}{|c|}{ Surgery } \\
\hline & & & & & Pre-op & Range & & & Plates & Buckle & SFT \\
\hline 1 & $\begin{array}{l}\text { Cleavage defect, } \\
\text { aphakic }\end{array}$ & $\mathrm{L}$ & $22 \mathrm{y} 9 \mathrm{~m}$ & $\begin{array}{l}\text { Cyclodialysis } \times 3 \\
\text { Cyclodiathermy } \times 1 \\
\text { Iridectomy } \times 2\end{array}$ & 20 & $20-48$ & Acet, Adren & PL & 2 & No & No \\
\hline 2 & Congenital glaucoma & $\mathrm{L}$ & $21 \mathrm{y} 1 \mathrm{~m}$ & Scheie's $\times 1$ & 35 & $24-35$ & Acet, Adren, Carb & $6 / 12$ & 2 & Yes & Yes \\
\hline 3 & $\begin{array}{l}\text { Congenital glaucoma, } \\
\text { aphakic }\end{array}$ & $\mathrm{R}$ & $2 \mathrm{y} 5 \mathrm{~m}$ & $\begin{array}{l}\text { Goniotomy } \times 2 \\
\text { Trabeculectomy } \times 4 \\
\text { Cyclodiatherapy } \times 1 \\
\text { Lens extraction } \times 1\end{array}$ & 37 & $37-45$ & Acet & CS & 2 & Yes & Yes \\
\hline 4 & $\begin{array}{l}\text { Congenital glaucoma, } \\
\text { aphakic }\end{array}$ & $\mathrm{L}$ & $2 y 5 m$ & $\begin{array}{l}\text { Goniotomy } \times 2 \\
\text { Trabeculectomy } \times 4 \\
\text { Cyclodiatherapy } \times 1 \\
\text { Lens extraction } \times 1\end{array}$ & 37 & $32-50$ & Acet, Tim & CS & 2 & Yes & Yes \\
\hline 5 & Congenital glaucoma & $\mathrm{R}$ & $26 y$ & $\begin{array}{l}\text { Goniotomy } \times 2 \\
\text { Trephine } \times 1 \\
\text { Scheie's } \times 1 \\
\text { Sphincterotomy } \times 1\end{array}$ & 40 & $15-40$ & $\begin{array}{l}\text { Acet, Adren, } \\
\text { Isoptocarb }\end{array}$ & $6 / 36$ & 2 & Yes & Yes \\
\hline 6 & Congenital glaucoma & $\mathrm{L}$ & $26 y$ & $\begin{array}{l}\text { Goniotomy } \times 1 \\
\text { Scheie's } \times 1 \\
\text { Goniopuncture } \times 1\end{array}$ & 32 & $20-39$ & $\begin{array}{l}\text { Acet, Adren, } \\
\text { Isoptocarb }\end{array}$ & $6 / 60$ & 2 & Yes & Yes \\
\hline 7 & Congenital glaucoma & $\mathrm{R}$ & 6y $5 \mathrm{~m}$ & Goniotomy $\times 3$ & 23 & $18-28$ & Acet, Adren & $6 / 18$ & 2 & Yes & No \\
\hline 8 & $\begin{array}{l}\text { Aphakic, rubella, } \\
\text { microphthalmic }\end{array}$ & $\mathrm{R}$ & $10 \mathrm{y} 1 \mathrm{~m}$ & $\begin{array}{l}\text { Lens extraction } \times 1 \\
\text { Scheie's } \times 1 \\
\text { Cyclodialysis } \times 1 \\
\text { Cyclocryotherapy } \times 1 \\
\text { Cyclodiathermy } \times 1\end{array}$ & 36 & $36-59$ & Acet, Adren, Pilo & $\mathrm{CF}$ & 2 & Yes & Yes \\
\hline 9 & $\begin{array}{l}\text { Aphakic, rubella, } \\
\text { microphthalmic }\end{array}$ & $\mathrm{L}$ & $10 \mathrm{y} 1 \mathrm{~m}$ & $\begin{array}{l}\text { Lens extraction } \times 1 \\
\text { Cyclodialysis } \times 1 \\
\text { Trabeculectomy } \times 2 \\
\text { Cyclodiathermy } \times 1 \\
\text { Scheie's } \times 1\end{array}$ & 60 & $35-60$ & Acet, Pilo, Adren & $3 / 60$ & 2 & Yes & Yes \\
\hline 10 & $\begin{array}{l}\text { Rubella, aphakic, } \\
\text { microphthalmic }\end{array}$ & $\mathrm{R}$ & $20 y$ & $\begin{array}{l}\text { Lens extraction } \times 1 \\
\text { Capsulotomy } \times 1\end{array}$ & 32 & $27-32$ & Acet, Tim & $6 / 60$ & 2 & Yes & Yes \\
\hline 11 & $\begin{array}{l}\text { Rubella, aphakic, } \\
\text { microphthalmic }\end{array}$ & L & $20 \mathrm{y}$ & $\begin{array}{l}\text { Lens extraction } \times 1 \\
\text { Capsulotomy } \times 2\end{array}$ & 29 & $28-34$ & Acet, Tim & $6 / 60$ & 2 & Yes & Yes \\
\hline 12 & Aphakic & $\mathrm{R}$ & $\begin{array}{l}16 \mathrm{y} \\
10 \mathrm{~m}\end{array}$ & $\begin{array}{l}\text { Lens extraction } \times 2 \\
\text { Goniotomy } \times 3 \\
\text { Scheie's } \times 2 \\
\text { Sclerectomy } \times 1\end{array}$ & 33 & $33-50$ & Acet, Adren, PI & PL & 2 & No & Yes \\
\hline 13 & Aphakic & L & $\begin{array}{c}16 \mathrm{y} \\
10 \mathrm{~m}\end{array}$ & $\begin{array}{l}\text { Lens extraction } \times 1 \\
\text { Goniotomy } \times 2 \\
\text { Scheie's } \times 3 \\
\text { Sclerectomy } \times 2\end{array}$ & 20 & $12-35$ & Acet, Adren, PI & $2 / 60$ & 2 & No & Yes \\
\hline 14 & Uveitic, aphakic & $\mathrm{R}$ & $24 y$ & $\begin{array}{l}\text { Trabeculectomy } \times 1 \\
\text { Trephine } \times 1 \\
\text { Scheie's } \times 1\end{array}$ & 24 & $34-50$ & Acet, Pilo, Adren & $6 / 9$ & 1 & Yes & Yes \\
\hline 15 & Congenital glaucoma & $\mathrm{R}$ & $13 y 4 m$ & $\begin{array}{l}\text { Goniotomy } \times 3 \\
\text { Trabeculectomy } \times 1\end{array}$ & 24 & $15-25$ & Acet, Adren & $6 / 60$ & 2 & Yes & Tes \\
\hline 16 & Congenital glaucoma & $\mathrm{L}$ & $13 y 4 \mathrm{~m}$ & $\begin{array}{l}\text { Goniotomy } \times 3 \\
\text { Trabeculectomy } \times 1\end{array}$ & 20 & $15-23$ & Acet, Adren & $6 / 60$ & 2 & Yes & Yes \\
\hline 17 & Rubella, aphakic & $\mathrm{L}$ & $15 \mathrm{y} 6 \mathrm{~m}$ & $\begin{array}{l}\text { Lens extraction } \times 1 \\
\text { Needling } \times 1 \\
\text { Capsulotomy } \times 1 \\
\text { Iridectomy } \times 1\end{array}$ & 25 & $17-40$ & Adren, $\mathrm{PhI}$ & $6 / 36$ & 2 & Yes & Yes \\
\hline 18 & Congenital glaucoma & $\mathrm{R}$ & $13 y 8 m$ & Goniotomy $\times 1$ & 36 & $35-36$ & Acet, Adren & PL & 2 & No & Yes \\
\hline 19 & Congenital glaucoma & $\mathrm{L}$ & $12 \mathrm{y} 5 \mathrm{~m}$ & $\begin{array}{l}\text { Goniotomy } \times 2 \\
\text { Trabeculectomy } \times 1\end{array}$ & 18 & $14-35$ & Acet, Tim, Pilo & $\mathrm{HM}$ & 2 & No & Yes \\
\hline
\end{tabular}




\begin{tabular}{|c|c|c|c|c|c|c|c|c|c|c|c|}
\hline \multirow[b]{2}{*}{ Eye } & \multirow[b]{2}{*}{ Diagnosis } & \multirow[b]{2}{*}{$\mathrm{R} / \mathrm{L}$} & \multirow[b]{2}{*}{ Age } & \multirow{2}{*}{$\begin{array}{l}\text { Previous } \\
\text { treatment }\end{array}$} & \multicolumn{2}{|c|}{ IOP $(\mathrm{mmHg})$} & \multirow[b]{2}{*}{ Treatment } & \multirow{2}{*}{$\begin{array}{l}\text { Visual } \\
\text { acuity }\end{array}$} & \multicolumn{3}{|c|}{ Surgery } \\
\hline & & & & & Pre-op & Range & & & Plates & Buckle & SFT \\
\hline 20 & $\begin{array}{l}\text { Sturge-Weber } \\
\text { syndrome }\end{array}$ & $\mathrm{R}$ & $10 \mathrm{y} 7 \mathrm{~m}$ & Nil & 29 & $19-30$ & Tim, Pilo, Adren & $6 / 6$ & 2 & No & Yes \\
\hline 21 & Congenital glaucoma & $R$ & 2 days & Nil & 37 & 37 & Nil & $N M$ & 1 & No & No \\
\hline 22 & Congenital glaucoma & $\mathrm{L}$ & 2 days & Nil & 35 & 35 & Nil & $\mathrm{NM}$ & 1 & No & No \\
\hline 23 & Neurofibromatosis & $\mathrm{R}$ & 4 days & Nil & 29 & 29 & Nil & NM & 1 & No & No \\
\hline 24 & $\begin{array}{l}\text { Aphakic, } \\
\text { microphthalmic }\end{array}$ & $\mathrm{R}$ & $3 y 2 \mathrm{~m}$ & $\begin{array}{l}\text { Lens extraction } \times 1 \\
\text { Capsulotomy } \times 2\end{array}$ & 35 & $20-35$ & Acet, Tim & $\mathrm{PC} 1 / 2 \mathrm{M}$ & 2 & No & Yes \\
\hline 25 & $\begin{array}{l}\text { Aphakic, } \\
\text { microphthalmic }\end{array}$ & $\mathrm{L}$ & $3 y 2 m$ & Lens extraction $\times 1$ & 35 & $12-35$ & Acet, Tim & PC1m & 2 & No & Yes \\
\hline 26 & $\begin{array}{l}\text { Congenital glaucoma, } \\
\text { dislocated lens }\end{array}$ & $\mathrm{R}$ & $15 \mathrm{y} 11 \mathrm{~m}$ & Trabeculectomy $\times 1$ & 38 & $14-43$ & Acet, Prop & $6 / 18$ & 2 & No & No \\
\hline 27 & $\begin{array}{l}\text { Congenital glaucoma, } \\
\text { dislocated lens }\end{array}$ & $\mathrm{L}$ & $16 y 6 m$ & Nil & 18 & $13-46$ & Acet, Prop & $6 / 9$ & 2 & No & No \\
\hline 28 & $\begin{array}{l}\text { Sturge-Weber } \\
\text { syndrome }\end{array}$ & $\mathrm{L}$ & $11 \mathrm{y} 10 \mathrm{~m}$ & Nil & 30 & $20-30$ & Acet, Pilo & $6 / 60$ & 2 & No & No \\
\hline 29 & Aphakic & $\mathrm{L}$ & $1 \mathrm{y} 1 \mathrm{~m}$ & $\begin{array}{l}\text { Lens extraction } \times 1 \\
\text { Capsulotomy } \times 1\end{array}$ & 34 & $18-37$ & Betoptic & CS & 1 & No & No \\
\hline 30 & $\begin{array}{l}\text { Sturge-Weber } \\
\text { syndrome }\end{array}$ & $\mathrm{R}$ & $4 m$ & Nil & 35 & $30-35$ & Nil & CS & 1 & No & No \\
\hline 31 & Aniridia, aphakic & $\mathrm{L}$ & $26 y$ & $\begin{array}{l}\text { Trabeculectomy } \times 1 \\
\text { Lens extraction } \times 2\end{array}$ & 25 & 25 & Acet, Tim, Pilo & $1 / 60$ & 2 & No & No \\
\hline 32 & Aniridia & $\mathrm{R}$ & $14 y 2 m$ & Trabeculectomy $\times 1$ & 35 & 35 & Acet, Tim, Pilo & $3 / 60$ & 2 & No & Yes \\
\hline 33 & Aniridia & $\mathrm{L}$ & $14 y 2 m$ & Trabeculectomy $\times 3$ & 25 & 25 & Acet, Tim, Pilo & $1 / 60$ & 1 & No & Yes \\
\hline 34 & Congenital glaucoma & $\mathrm{R}$ & $9 \mathrm{y} 6 \mathrm{~m}$ & Nil & 31 & $31-60$ & Acet, Adren & $6 / 60$ & 2 & No & No \\
\hline
\end{tabular}

IOP is shown as the immediate pre-operative reading and the range of readings prior to Molteno drain insertion (second stage in twostage procedures).

$\mathrm{R}$, right; L, left; y, years; m, months; Acet, acetazolamide; Tim, timolol; Pilo, pilocarpine; Prop, propine; Adren, Adrenaline; Carb, carbechol; Isoptocarb, isoptocarbechol; PhI, phospholine iodide; NM, not measured; CS, can see; CF, count fingers; PL, perception of light; HM, hand movements; PC, picture cards; SFS, systemic fibrosis suppression.

follow-up, but had 4 years' follow-up available and is included in the study. Data were available on 34 eyes of 25 patients.

\section{Pre-operative status}

Of the 25 patients, 16 had associated ocular findings in addition to glaucoma including: 10 patients (15 eyes) with aphakia; 3 patients ( 3 eyes) with Sturge-Weber syndrome; 1 patient ( 1 eye) with neurofibromatosis; 3 patients ( 5 eyes) with rubella syndrome; 3 patients $(6$ eyes) with microphthalmia; 1 patient ( 2 eyes) with dislocated lenses; 1 patient (1 eye) with a cleavage defect; 1 patient ( 1 eye) who was uveitic; and 2 patients ( 3 eyes) who were aniridic. The number of previous surgical procedures that each eye had undergone ranged from 0 to 8 (mean 3.0). Patient age at time of first Molteno drain ranged from 2 days to 26 years. Pre-operative IOPs were recorded as immediate pre-operative IOP (prior to the first stage in a two-stage procedure) and the range recorded as the IOPs in the 6 weeks prior to surgery. Mean pre-operative IOP was $31.0 \mathrm{mmHg}$ and the range is shown in Table 1 . Pre-operatively 4 patients ( 5 eyes) were not on any treatment; 18 patients were on systemic acetazolamide; and the mean number of topical medications per eye was 1.3 (range $0-3$ ). Visual acuity (where recorded) ranged from $6 / 6$ to perception of light. These data are shown in Table 1.

\section{Surgical procedures}

Thirty-eight Molteno drains were placed in 34 eyes, with 2 eyes having their drains replaced and 2 eyes having additional drains inserted. As first procedures, 27 eyes had a double plate drain inserted (19 eyes as a two-stage procedure without a Vicryl tie; 5 as a one-stage procedure with a Vicryl tie; 2 as a one-stage procedure without a Vicryl tie; and 1 as a one-stage procedure using a pressure ridge dual chamber drain with Vicryl tie). Seven eyes received a single plate drain (1 as a two-stage procedure without a Vicryl tie; 1 as a two-stage procedure with a pressure ridge dual chamber drain and Vicryl tie with tube to the posterior chamber via the pars plana; 3 as a one-stage procedure without a Vicryl tie; and 2 as a one-stage procedure with a pressure ridge dual chamber drain).

The surgical technique used has been described previously and differs slightly for one- and two-stage procedures. Briefly, the conjunctiva and Tenon's capsule were lifted at the limbus and dissected posteriorly. 
Table 2. Pre-operative surgical procedures (mean number per eye) in eyes that received an antifibrosis regime versus eyes that did not

\begin{tabular}{lcc}
\hline & Antifibrosis regime (22 eyes) & No antifibrosis regime (12 eyes) \\
\hline $\begin{array}{l}\text { No. of previous drainage operations } \\
\text { (trabeculectomy, Scheie, sinusotomy, sclerectomy) }\end{array}$ & 1.6 & 0.2 \\
No. of goniotomies or goniopuncture & 1.0 & 0.2 \\
Cyclodialysis, cyclodiathermy, cyclocryotherapy & 0.3 & 0.3 \\
\hline
\end{tabular}

Double plate drains were sutured to the sclera with a $7 / 0$ silk suture either side of the superior rectus muscle, with single plate drains being sutured to either the nasal or temporal side of the muscle. In the two-stage procedure, the tube was then placed under a triangular partialthickness scleral flap, with the end of the tube being placed under the medial rectus muscle. In the one-stage procedure, a partial-thickness scleral flap was lifted to the limbus and the tube (after trimming to length) was placed into the anterior chamber via a paracentesis created with either a 22 or 23 gauge needle. In the cases in which it was used, a 5/0 Vicryl tie was then tied around the tube and its occluded lumen confirmed by attempting to irrigate balanced salt solution down the tube. The scleral flap was then replaced and sutured with either a $7 / 0$ silk or $8 / 0$ vicryl suture. In the two-stage procedure, after 4-6 weeks the conjunctiva and Tenon's capsule were lifted and the tube retrieved from under the rectus muscle. It was then placed into the anterior chamber in the same manner as for the one-stage procedure. At the end of the procedure, a subconjunctival injection of steroid and antibiotic was given. In addition, 14 eyes received a $360^{\circ}$ buckle at the same time as the first procedure, to reduce the risk of later retinal detachment.

\section{Post-operative medication}

Post-operative medication consisted of topical steroids, adrenaline and atropine in all cases. In 22 of the most severely damaged eyes the antifibrosis regime of prednisolone, fluphenamic acid and colchicine previously described by Molteno ${ }^{1}$ was used (diclofenac was substituted for fluphenamic acid in one case). The regime was given for 4-6 weeks after the second-stage operations or when the Vicryl tie dissolved and aqueous started to drain into the preformed bleb systems consisting of fibrous tissue enclosing the episcleral plates of the implants.

The criteria for choosing cases for fibrosis suppression medication included: (1) failure of previous drainage operations, (2) the presence of uveitis, (3) congested eyes with a very high IOP and (4) terminal disease with grossly enlarged eyes. The differences between eyes receiving fibrosis suppression and those not are shown in Table 2 .

\section{Results \\ IOP outcome}

Follow-up ranged from 9 months to 16 years 9 months (mean 11.2 years). IOP outcome was defined as complete success if the IOP was $<22 \mathrm{mmHg}$ without treatment, partial success if the IOP was $<22 \mathrm{mmHg}$ with treatment, and as a failure if the IOP was $>21 \mathrm{mmHg}$ or the eye was phthisical. By our definition, the IOP was controlled in $85 \%$ of cases. This included eye 23 in which the raised IOP was cured prior to enucleation for cosmetic reasons. Two eyes that failed had an IOP of 22 and $23 \mathrm{mmHg}$ respectively, and although this was a failure by our definition, we felt that clinically the eyes were reasonably well controlled. If these two eyes are included, then $91.2 \%$ of eyes were cured or controlled (Table 3). Eighty-two per cent of the most severely damaged eyes that received the antifibrosis regime were controlled, compared with $92 \%$ of eyes that did not. Eighty-seven per cent of eyes that had had up to three previous surgical procedures, were controlled, compared with $82 \%$ of eyes that had had more than three procedures.

\section{Visual outcome}

Final visual acuity range from $6 / 9$ to no perception of light, and was comparable with pre-operative levels in 28 eyes. We defined visual outcomes as maintained if the vision was within 1 Snellen line, deteriorated if acuity was 2 or more lines worse than the pre-operative level, and lost if the eye was blind or enucleated. By this definition, in eyes in which vision was comparable, $57 \%$ maintained their pre-operative vision. Sixty-seven per cent of eyes that had up to three previous surgical procedures maintained their pre-operative vision, compared with $40 \%$ of eyes that had had more than three procedures.

Fifty per cent of eyes maintained their vision and had the IOP controlled. If the two eyes that had IOPs of 22 and $23 \mathrm{mmHg}$ are included, this figure rises to $57 \%$.

\section{Complications and further surgery}

Two eyes (one with Sturge-Weber syndrome) had a choroidal detachment and flat anterior chamber in the early post-operative period that resolved spontaneously. Three eyes developed a corneal ulcer, and 2 eyes had an episode of iritis. Seven eyes developed band keratopathy. Twenty-four of the 34 eyes $(71 \%)$ required further surgery (Table 4 ), with 10 eyes $(29 \%)$ having more than one procedure over the follow-up period. Two eyes had their Molteno drains replaced and 2 eyes had additional Molteno drains inserted; the combined follow-up for these eyes is shown in Table 3. Three eyes had the tube shortened (as it was in the visual axis), and 3 eyes had the tube repositioned into the posterior chamber for corneal problems ( 2 following two attempts to reposition the tube in the anterior chamber). One eye had the 


\begin{tabular}{|c|c|c|c|c|c|c|}
\hline \multirow[b]{2}{*}{ Eye } & \multirow[b]{2}{*}{ Follow-up } & \multirow[b]{2}{*}{ IOP $(\mathrm{mmHg})$} & \multirow[b]{2}{*}{ Treatment } & \multirow[b]{2}{*}{ Acuity } & \multicolumn{2}{|c|}{ Outcome } \\
\hline & & & & & $\mathrm{IOP}^{\mathrm{a}}$ & Acuity $^{\mathrm{b}}$ \\
\hline $1^{\mathrm{c}}$ & $13 \mathrm{y} 4 \mathrm{~m}$ & 14 & Acet, Tim & NPL & PS & Lost \\
\hline 2 & $16 \mathrm{y} 6 \mathrm{~m}$ & 16 & Acet, Tim & $6 / 36$ & PS & Deteriorated \\
\hline 3 & $12 y$ & 15 & Nil & PL & CS & $\mathrm{NC}$ \\
\hline 4 & $12 y$ & $\mathrm{Ph}$ & $\mathrm{Nil}$ & NPL & Fail & Lost \\
\hline 5 & $15 \mathrm{y} 4 \mathrm{~m}$ & 20 & Acet, Tim & $3 / 60$ & PS & Deteriorated \\
\hline 6 & $15 \mathrm{y} 4 \mathrm{~m}$ & 20 & Acet, Tim & $\mathrm{HM}$ & PS & Deteriorated \\
\hline 7 & $15 \mathrm{y} 8 \mathrm{~m}$ & 20 & Nil & $6 / 60$ & CS & Deteriorated \\
\hline $8^{c}$ & $2 \mathrm{y} 3 \mathrm{~m}$ & 15 & Acet, Tim & NPL & PS & Lost \\
\hline 9 & $15 y 7 m$ & 18 & Tim & $1 / 60$ & PS & Deteriorated \\
\hline 10 & $14 \mathrm{y} 10 \mathrm{~m}$ & 23 & Acet, Adren & $6 / 60$ & Fail & Maintained \\
\hline 11 & $14 \mathrm{y} 10 \mathrm{~m}$ & 19 & Acet, Adren & $6 / 60$ & PS & Maintained \\
\hline 12 & $15 y 6 m$ & 17 & Nil & PL & CS & Maintained \\
\hline 13 & $15 \mathrm{y} 6 \mathrm{~m}$ & 17 & Tim & $6 / 60$ & PS & Maintained \\
\hline 14 & $16 y 9 m$ & 13 & Nil & $6 / 24$ & CS & Deteriorated \\
\hline 15 & $14 \mathrm{y} 11 \mathrm{~m}$ & $\mathrm{Ph}$ & $\mathrm{Nil}$ & NPL & Fail & Lost \\
\hline 16 & $14 \mathrm{y} 11 \mathrm{~m}$ & 16 & Tim & $6 / 48$ & PS & Maintained \\
\hline 17 & $13 y 4 m$ & 18 & Tim, Prop & $6 / 36$ & PS & Maintained \\
\hline 18 & $14 \mathrm{y} 8 \mathrm{~m}$ & 16 & Nil & $\mathrm{HM}$ & CS & Maintained \\
\hline 19 & $4 y$ & 20 & Nil & $\mathrm{HM}$ & CS & Maintained \\
\hline 20 & $12 \mathrm{y} 9 \mathrm{~m}$ & 22 & Adren & $6 / 9$ & Fail & Maintained \\
\hline 21 & $10 \mathrm{y} 4 \mathrm{~m}$ & 11 & Nil & $6 / 12$ & $\mathrm{CS}$ & $\mathrm{NC}$ \\
\hline 22 & $9 y \quad 8 m$ & 11 & $\mathrm{Nil}$ & $1 / 60$ & CS & NC \\
\hline$\overline{23^{c}}$ & $9 \mathrm{~m}$ & 10 & Nil & NPL & CS & $\mathrm{NC}$ \\
\hline 24 & $10 \mathrm{y} 10 \mathrm{~m}$ & 18 & $\mathrm{Nil}$ & $6 / 24$ & CS & Maintained \\
\hline 25 & $10 \mathrm{y} 10 \mathrm{~m}$ & 16 & Tim & $6 / 24$ & PS & Maintained \\
\hline $26^{\mathrm{c}}$ & $4 y$ & $\mathrm{Ph}$ & Nil & NPL & Fail & Lost \\
\hline 27 & $10 y$ & 12 & Tim & $6 / 12$ & PS & Maintained \\
\hline 28 & $10 \mathrm{y} 6 \mathrm{~m}$ & 20 & Tim & HM & PS & Deteriorated \\
\hline 29 & $3 y 3 m$ & 12 & Tim & $6 / 20$ & PS & $\mathrm{NC}$ \\
\hline 30 & $13 y 3 m$ & 21 & Tim & $\mathrm{CF}$ & PS & $\mathrm{NC}$ \\
\hline 31 & $9 y 6 m$ & 15 & Tim & $1 / 60$ & PS & Maintained \\
\hline 32 & $7 y \quad 10 m$ & 16 & Acet & $3 / 60$ & PS & Maintained \\
\hline 33 & $7 \mathrm{y} 10 \mathrm{~m}$ & 18 & Acet & $1 / 60$ & PS & Maintained \\
\hline 34 & 3y 3m & 16 & Adren & $6 / 60$ & PS & Maintained \\
\hline
\end{tabular}

IOP, Intraocular pressure; $y$, years; $\mathrm{m}$, months; Adren, adrenaline; Tim, timolol; Prop, propine; Acet, acetazolamide; $\mathrm{CF}$, count fingers; HM, hand movements; NPL, no perception of light; Ph, phthisical.

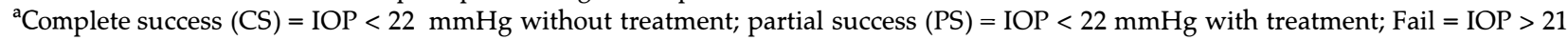
$\mathrm{mmHg}$ or phthisical.

${ }^{\mathrm{b}}$ Maintained = acuity within 1 Snellen line of pre-operative level; deteriorated = acuity 2 or more lines worse than pre-operative level; Lost $=$ blind or enucleated; NC $=$ non-comparable.

'IOP readings taken prior to enucleation and visual acuity recorded as NPL.

connecting tube between two plates unblocked. Two eyes had patch grafts to prevent erosion of the tube through the conjunctiva. Five eyes had division of adhesions or synechiae. One eye has had an iridectomy and 1 a sphincterotomy. Five eyes had cataract extractions (1 combined with vitrectomy), and 5 eyes had undergone vitrectomy ( 1 for tube blockage, and 4 for pigment or blood in the vitreous). Two eyes had unsuccessful retinal detachment surgery, and 1 eye has a localised inferior retinal detachment that has not undergone surgery and

Table 4. Further surgery (number of eyes undergoing each procedure)

\begin{tabular}{llll}
\hline Drain replaced & 2 & Vitrectomy & 5 \\
$\begin{array}{l}\text { Drain added } \\
\text { Tube reposition }\end{array}$ & 2 & Cataract extraction & 5 \\
AC & 4 & Retinal detachment & 2 \\
PC & 3 & Enucleation & 4 \\
Tube shortened & 3 & Synechiae division & 5 \\
Tube erosion & 2 & Iridectomy & 1 \\
Unblocking of & & Sphincterotomy & 1 \\
$\quad$ interconnecting tube & 1 & Corneal graft & 1 \\
\hline
\end{tabular}

$\mathrm{AC}$, anterior chamber; $\mathrm{PC}$, posterior chamber. retains a vision of $6 / 36$. One eye has had three corneal grafts and retains $6 / 60$ vision. Four eyes have been enucleated. One eye became blind and phthisical 7 years after tube insertion, following an intraocular haemorrhage of unknown origin.

\section{Discussion \\ IOP control}

In this study we have examined the long-term outcome (mean follow-up 11.2 years) of Molteno drains in the treatment of glaucoma presenting in childhood. Many of the eyes in this study had undergone multiple previous surgical procedures prior to drain placement, and today these eyes would receive their drains at an earlier stage in the disease process, which may influence their outcome. Despite this, $85 \%$ of eyes had their IOP cured or controlled on long-term follow-up. Previous reported studies have differing criteria for the definition of success and this makes comparison difficult. Also the surgical procedure (one- or two-stage) and the number of plates 
Table 5. Success of intraocular pressure (IOP) control in reported series, with the use of Molteno drains in glaucoma presenting in childhood

\begin{tabular}{|c|c|c|c|c|c|c|}
\hline Author & Year & No. of eyes & Follow-up (months) & Age (years) & Success & IOP definition \\
\hline Goldberg $^{27}$ & 1987 & 15 & Up to 18 & Up to 36 & $100 \%$ & $<20 \mathrm{mmHg} \pm \mathrm{Rx}$ \\
\hline Minckler $^{28}$ & 1988 & 13 & Mean 22.8 & $<13$ & $54 \%$ & $\leqslant 21 \mathrm{mmHg} \pm \mathrm{Rx}$ \\
\hline Traverso $^{29}$ & 1989 & 44 & Median 11 & $?$ & $70 \%^{a}$ & $\leqslant 19 \mathrm{mmHg} \pm \mathrm{Rx}$ \\
\hline Billson $^{30}$ & 1989 & 23 & Mean 41 & Up to 46 & $78 \%$ & $\leqslant 21 \mathrm{mmHg} \pm \mathrm{Rx}$ \\
\hline Munoz $^{31}$ & 1991 & 53 & Mean 18 & $<12$ & $68 \%$ & $\leqslant 21 \mathrm{mmHg} \pm \mathrm{Rx}$ \\
\hline Hill $^{32}$ & 1991 & 65 & Mean 22.7 & $<21$ & $62 \%$ & $\leqslant 21 \mathrm{mmHg} \pm \mathrm{Rx}$ \\
\hline Nesher $^{33}$ & 1992 & 27 & Mean 20 & Up to 13 & $59 \%$ & $\leqslant 21 \mathrm{mmHg} \pm \mathrm{Rx}$ \\
\hline Lloyd $^{34}$ & 1992 & 16 & Mean 49.1 & $<13$ & $44 \%$ & $\leqslant 21 \mathrm{mmHg} \pm \mathrm{Rx}$ \\
\hline Netland $^{35}$ & 1993 & 13 & Mean 32 & $\leqslant 10$ & $77 \%$ & $\leqslant 21 \mathrm{mmHg} \pm \mathrm{Rx}$ \\
\hline
\end{tabular}

Rx, therapy.

${ }^{\text {a }}$ Calculated at 1 year.

used (one or two) differs within and between studies. However, taking these limitations into account, these results compare favourably with other published series with shorter follow-up. These previous reports are summarised in Table 5. In this study, the selective use of the antifibrosis regime appears to have improved the results in the worst cases, since the number of previous surgical interventions did not influence the outcome of surgery in terms of IOP control. However, the varied aetiologies and small numbers preclude any definite conclusions from this series.

\section{Visual outcome}

In this study $57 \%$ of eyes (in which we were able to make a comparison) have maintained their vision at final follow-up. This is comparable with previous studies in which Minckler et al., ${ }^{28}$ Hill et al. ${ }^{32}$ and Lloyd et al. ${ }^{34}$ reported vision being maintained within 1 line of preoperative levels in $100 \%, 68 \%$ and $63 \%$ of eyes respectively, and Munoz et al. ${ }^{31}$ reported vision being the same or better in $76 \%$ of cases.

From the patient's perspective the visual outcome is the main indicator of success. In the eyes in which we were able to compare pre- and post-operative vision, 12 either deteriorated or lost their vision. In 1 eye, vision deteriorated after an episode of raised pressure that was resolved by unblocking the connecting tube between two plates. In an eye with initial poor vision (PL) the drain failed to control IOP and the eye became blind.

Enucleation was precipitated in 1 eye by perforation of an infected corneal ulcer in an eye with fluctuating pressure control, poor vision, and a persistently (present before tube placement) oedematous cornea. Another eye was enucleated for pain secondary to bullous keratopathy. Two eyes, in which the vision had not deteriorated, had undergone multiple surgical procedures before and/or after Molteno drain placement and eventually became phthisical despite pressure control. Phthisis could be related to unsuccessful retinal detachment surgery occurring 7 months after drain placement in 1 eye. In 1 eye with a pre-operative vision of $<3 / 60$ with advanced glaucoma and multiple previous procedures, vision deteriorated over 15 years of followup, despite control of IOP. In a further 4 eyes, vision deteriorated despite IOP control, with no obvious cause being found for the reduced vision. Therefore, of the 12 eyes that measurably deteriorated, in only 2 (the first 2 described here) can the deterioration be directly related to tube problems. In the other eyes it seemed to be the general condition of the eye and the number of previous surgical procedures that influenced the visual outcome. Unfortunately 1 eye in this series, with Sturge-Weber syndrome (whose pre-operative acuity was not recorded at the age of 4 months), was noted to have an acuity of $6 / 12$ at the age of 5 years but then spectacle wear was discontinued and, despite control of IOP, the acuity has dropped to count fingers. Some of the loss of acuity may be attributable to treatable amblyopia. This case thus illustrates the importance of correcting refractive errors and treating amblyopia as part of the follow-up of these cases.

\section{Further surgery and complications}

In the series, $71 \%$ of eyes required further surgery with $29 \%$ having more than one procedure, and 32\% being for drain-related problems. In Hill et al.'s study ${ }^{32} 83 \%$ of cases required further surgery, as did $44 \%$ of cases in Nesher et al.'s series.

In 4 eyes the Molteno drain was either replaced or a further drain added to facilitate pressure control. Three of these eyes $(75 \%)$ have maintained good pressure control at latest follow-up. In this series 7 eyes had the tube repositioned (for cornea-related problems) or shortened, and in 2 eyes the tube eroded through the sclera requiring patch grafts. One eye required vitrectomy due to vitreous blocking the tube. These complications, often requiring further surgery, occur in many reported series ${ }^{28-36}$ and may be avoided by careful, accurate placement of the tube into the anterior chamber. The tube is best positioned parallel to the iris plane and just in front of it. The tube should also be bevelled anteriorly to help prevent blockage by iris. Where vitreous is present, for example in aphakic eyes, a good anterior vitrectomy should clear any residual vitreous from entering the end of the tube. It may also be appropriate in these eyes to place the tube through the pars plana into the posterior chamber with its tip visible in the pupil (but not in the visual axis), so as to avoid occlusion by iris and to remove the risk of corneal touch. One tube that had to be shortened in this study was initially placed in the eye of a 2-day-old baby with congenital glaucoma and on examination at day 10 was 
noted to be in the visual axis. At over 10 years follow-up this eye has good IOP control and a vision of $6 / 12$. In this study one eye had blockage of the interconnecting tube between two plates at 10 years post-operatively, when the eye was noted to have a raised IOP with one bleb distended while the bleb overlying the other plate was flat. This interconnecting tube was unblocked at surgery and the eye now has distended blebs over both plates and a controlled IOP.

Other surgical intervention was required in 19 eyes. These interventions included cataract extraction, retinal detachment repair, vitrectomy, enucleation, iridectomy, sphincterotomy and synechiae division; 1 eye underwent three corneal grafts. The need for these interventions reflects the presence of associated anomalies and the damage done by severe glaucoma and repeated surgical interventions during early childhood.

\section{Conclusions}

In summary, this series reports the long-term follow-up of Molteno drains used in eyes with glaucoma presenting in childhood, and shows that they can maintain good pressure control and visual function. Seventy-one per cent of eyes required further surgical intervention. Thirty-two per cent of cases were for drain-related problems, which may be avoidable with current surgical techniques. The remaining interventions were for associated ocular defects, and for problems caused by multiple surgical procedures and periods of high IOP during early childhood. Today we use the implants earlier in the disease process to try to obtain early and definitive IOP control and so help optimise the long-term visual prognosis.

\section{References}

1. Molteno ACB, Ancker E, Van Biljon G. Surgical techniques for advanced juvenile glaucoma. Arch Ophthalmol 1984;102:51-7.

2. Luntz MH. Congenital, infantile, and juvenile glaucoma. Ophthalmology 1979;86:793-802.

3. Anderson DR. Trabeculotomy compared to goniotomy for glaucoma in children. Ophthalmology 1983;90:805-6.

4. DeLuise VP, Anderson DR. Primary infantile glaucoma (congenital glaucoma). Surv Ophthalmol 1983;28:1-19.

5. Shaffer RN, Hoskins HD. Goniotomy in the treatment of isolated trabeculodysgenesis (primary congenital [infantile] developmental glaucoma). Trans Ophthalmol Soc UK 1983;103:581-5.

6. Quigley HA. Childhood glaucoma: results with trabeculotomy and study of reversible cupping. Ophthalmology 1982;89:219-26.

7. McPherson SD, McFarland D. External trabeculotomy for developmental glaucoma. Ophthalmology 1980;87:302-5.

8. Burke JP, Bowell R. Primary trabeculectomy in congenital glaucoma. Br J Ophthalmol 1989;73:186-90.

9. Elder MJ. Combined trabeculotomy-trabeculectomy compared with primary trabeculectomy for congenital glaucoma. Br J Ophthalmol 1994;78:745-8.

10. Joseph A. Trabeculectomy in congenital glaucoma. Indian J Ophthalmol 1981;29:81-2.

11. O'Connor G. Combined trabeculotomy-trabeculectomy for congenital glaucoma. Br J Ophthalmol 1994;78:735.
12. Miller MH, Rice MSC. Trabeculectomy combined with betairradiation for congenital glaucoma. Br J Ophthalmol 1991;75:584-90.

13. Whiteside-Michel J, Leibmann JM, Ritch R. Initial 5 -fluorouracil trabeculectomy in young patients. Ophthalmology 1992;99:7-13.

14. Zalish M, Leiba $\mathrm{H}$, Oliver M. Subconjunctival injection of 5-fluorouracil following trabeculectomy for congenital and infantile glaucoma. Ophthalmic Surg 1992;23:203-5.

15. Herschler J. Commentary. Ophthalmic Surg 1992;23:205.

16. Gressel MG, Heuer DK, Parrish RK. Trabeculectomy in young patients. Ophthalmology 1984;91:1242-6.

17. Beauchamp GR, Parks MM. Filtering surgery in children: barriers to success. Ophthalmology 1979;86:170-9.

18. Debnath SC, Teichmann KD, Salamah K. Trabeculectomy versus trabeculotomy in congenital glaucoma. $\mathrm{Br} \mathrm{J}$ Ophthalmol 1989;73:608-11.

19. Sturmer J, Broadway DC, Hitchings RA. Young patient trabeculectomy: assessment of risk factors for failure. Ophthalmology 1993;100:928-39.

20. Cadera W, Pachtman MA, Cantor LB, Ellis FD, Helveston EM. Filtering surgery in childhood glaucoma. Ophthalmic Surg 1984;15:319-22.

21. Iwach AG, Hoskins HD, Hetherington J, Shaffer RN. Analysis of surgical and medical management of glaucoma in Sturge-Weber syndrome. Ophthalmology 1990;97:904-9.

22. Wiggins RE, Tomey KF. The results of glaucoma surgery in aniridia. Arch Ophthalmol 1992;110:503-5.

23. Caprioli J, Strang SL, Spaeth GL, Poryzees EH. Cyclocryotherapy in the treatment of advanced glaucoma. Ophthalmology 1985;92:947-54.

24. Bellows AR, Grant WM. Cyclocryotherapy in advanced inadequately controlled glaucoma. Am J Ophthalmol 1973;75:679-84.

25. Al Faran FM, Tomey KF, Al Mutlaq FA. Cyclocryotherapy in selected cases of congenital glaucoma. Ophthalmic Surg 1990;21:794-8.

26. Aminlari A. Cyclocryotherapy in congenital glaucoma. Glaucoma 1981;331-2.

27. Goldberg I. Management of uncontrolled glaucoma with the Molteno system. Aust NZ J Ophthalmol 1987;15:97-107.

28. Minckler DS, Heuer DK, Hasty B, Baerveldt G, Cutting RC, Barlow WE. Clinical experience with the single plate Molteno implant in complicated glaucomas. Ophthalmology 1988;95:1181-8.

29. Traverso CE, Tomey KF, Al-Kaff A. The long-tube single plate Molteno implant for the treatment of recalcitrant glaucoma. Int Ophthalmol 1989;13:159-62.

30. Billson F, Thomas R, Aylward W. The use of two-stage Molteno implants in developmental glaucoma. J Pediatr Ophthalmol Strabismus 1989;26:3-8.

31. Munoz M, Tomey KF, Traverso C, Day SH, Senft SH. Clinical experience with the Molteno implant in advanced infantile glaucoma. J Pediatr Ophthalmol Strabismus 1991;28:68-72.

32. Hill RA, Heuer DK, Baerveldt G, Minckler DS, Martone JF. Molteno implantation for glaucoma in young patients. Ophthalmology 1991;98:1042-6.

33. Nesher R, Sherwood MB, Kass MA, Hines JL, Kilker AE. Molteno implants in children. Glaucoma 1992;1:228-32.

34. Lloyd MA, Sedlak T, Heuer DK, Minckler DS, Baerveldt G, Lee MB, Martone JF. Clinical experience with the single plate Molteno implant in complicated glaucomas: update of pilot study. Ophthalmology 1992;99:679-87.

35. Netland PA, Walton DS. Glaucoma drainage implants in paediatric patients. Ophthalmic Surg 1993;24:723-9.

36. Airaksinen PJ, Aisala P, Yuulonen A. Molteno implant surgery in uncontrolled glaucoma. Acta Ophthalmol (Copenh) 1990;68:690-4.

37. Freedman J, Rubin B. Molteno implants as a treatment for refractory glaucoma in black patients. Arch Ophthalmol 1991;109:1417-20. 